\title{
A rarely diagnosed cause of anterior knee pain: Hoffa's disease
}

\author{
Ali Kemal Sivrioglu, ${ }^{1}$ Selahattin Ozyurek, ${ }^{2}$ Mehmet Incedayi, ${ }^{3}$ Hakan Mutlu ${ }^{3}$
}

${ }^{1}$ Aksaz Military Hospital, Department of Radiology, Mugla, Turkey

${ }^{2}$ Aksaz Military Hospital, Department of Orthopaedics and Traumatology, Mugla,

Turkey

${ }^{3}$ GATA Haydarpasa Teaching Hospital, Department of Radiology, Istanbul, Turkey

\section{Correspondence to} Dr Mehmet Incedayi, m_incedayi@yahoo.com
To cite: Sivrioglu AK, Ozyurek S, Incedayi M, et al. BMJ Case Rep Published online: [please include Day Month Year] doi:10.1136/ bcr-2013-008795

\section{DESCRIPTION}

A 23-year-old football player presented with a 6-month history of mild pain on the anterior part of his right knee. Physical examination showed moderate swelling and restricted motion of the knee. Radiographs of the right knee revealed an increase in density in the infrapatellar fat pad (Hoffa's fat pad). Sagittal T1-weighted MRI showed hypointensity in the enlarged infrapatellar fat pad (figure 1). Sagittal and axial T2-weighted MRI revealed hyperintensity at the same localisation, minimal joint effusion and meniscus tears (figure 2A,B). The findings were compatible with inflammation of the infrapatellar fat pad. The diagnosis was made as Hoffa's disease. The lesion was excised arthroscopically. Histopathological examination confirmed Hoffa's disease.

Although the precise function of the infrapatellar fat pad is still unknown, the structure has clinical importance as the location of various tumour and tumour-like abnormalities such as para-articular chondroma or osteochondroma, Hoffa's disease, focal pigmented villo-nodular synovitis, synovial chondromatosis, lipoma, haemangioma, ganglion cysts and chondrosarcoma. ${ }^{1}$ Hoffa's disease is an obscure cause of anterior knee pain resulting from impingement and inflammation of the infrapatellar fat pad due to acute or chronic repetitive microtrauma. ${ }^{2}$ While inflammation is prominent during

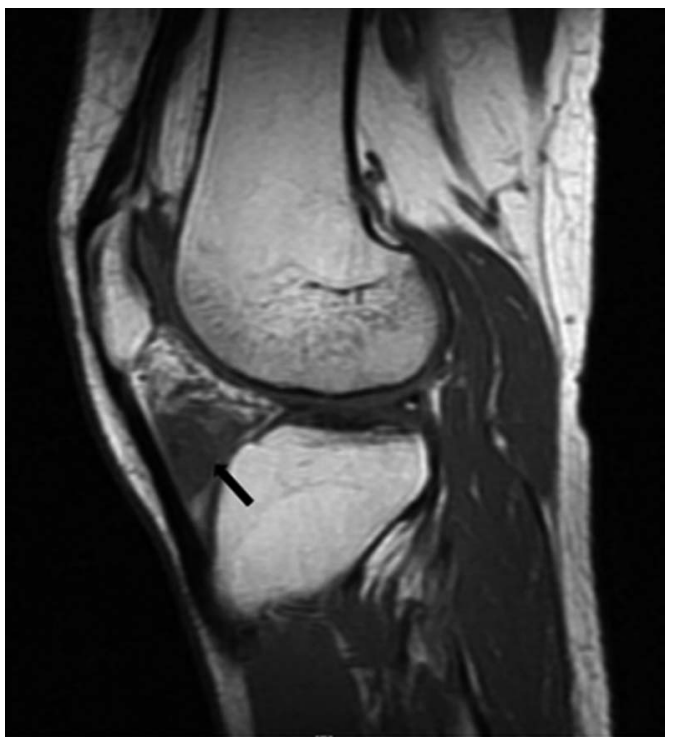

Figure 1 Sagittal T1-weighted MRI showing hypointensity in the enlarged infrapatellar fat pad.

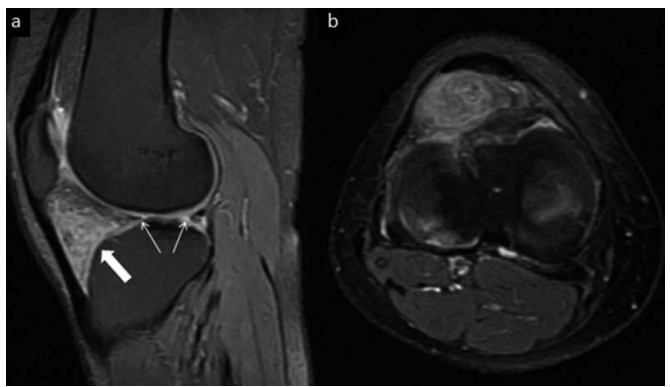

Figure 2 ( $A$ and B) Sagittal and axial T2- weighted magnetic resonance images reveal hyperintensed infrapatellar fat pad (large arrow), minimal joint effusion and meniscus tears (thin arrows).

the acute phase of the disease, impingement due to fibrosis and scar tissue of the infrapatellar fat pad plays a major role in the chronic phase. ${ }^{3}$ Fibrous tissue may be transformed into fibrocartilaginous tissue and it may ossify. Hoffa's disease should be considered in the differential diagnosis of anterior knee pain.

\section{Learning points}

Hoffa's disease is an obscure and rarely diagnosed cause of anterior knee pain.

- Increased awareness of this clinical entity is required for early diagnosis and to facilitate the appropriate treatment, thus preventing morbidity of the patient.

Contributors AKS made the conception and design. SO treated the patient and drafted the manuscript. MI and HM participated in the design of the study. All authors read and approved the final manuscript.

Competing interests None.

Patient consent Obtained.

Provenance and peer review Not commissioned; externally pee reviewed.

\section{REFERENCES}

1 Sakai H, Tamai K, Iwamoto A, et al. Para-articular chondroma and osteochondroma of the infrapatellar fat pad: a report of three cases. Int Orthop 1999;23:114-17.

2 Hoffa A. Influence of adipose tissue with regard to the pathology of the knee joint. JAMA 1904;43:795-6.

3 Turhan E, Doral MN, Atay AÖ, et al. A giant extrasynovial osteochondroma in the infrapatellar fat pad: end stage Hoffa's disease. Arch Orthop Trauma Surg 2008;128:515-19. 
Copyright 2013 BMJ Publishing Group. All rights reserved. For permission to reuse any of this content visit http://group.bmj.com/group/rights-licensing/permissions.

BMJ Case Report Fellows may re-use this article for personal use and teaching without any further permission.

Become a Fellow of BMJ Case Reports today and you can:

- Submit as many cases as you like

- Enjoy fast sympathetic peer review and rapid publication of accepted articles

- Access all the published articles

- Re-use any of the published material for personal use and teaching without further permission

For information on Institutional Fellowships contact consortiasales@bmjgroup.com

Visit casereports.bmj.com for more articles like this and to become a Fellow 